\title{
Hybrid
}

Revue des arts et médiations humaines

\section{Fluid fiction: Daniel Canty's transmedia odyssey}

\section{René Audet and Charles-Antoine Fugère}

Translator. Tresi Murphy

\section{(2) OpenEdition}

\section{Journals}

Electronic version

URL: https://journals.openedition.org/hybrid/418

DOI: $10.4000 /$ hybrid. 418

ISSN: 2276-3538

This article is a translation of:

Fictions fluides : les odyssées transmédiatiques de Daniel Canty - URL : https:// journals.openedition.org/hybrid/333 [fr]

\section{Publisher}

Presses universitaires de Vincennes

\section{Electronic reference}

René Audet and Charles-Antoine Fugère, "Fluid fiction: Daniel Canty's transmedia odyssey", Hybrid [Online], 5 | 2018, Online since 18 December 2018, connection on 15 April 2022. URL: http:// journals.openedition.org/hybrid/418; DOI: https://doi.org/10.4000/hybrid.418

This text was automatically generated on 15 April 2022.

Revue Hybrid 


\title{
Fluid fiction: Daniel Canty's transmedia odyssey
}

\author{
René Audet and Charles-Antoine Fugère
}

Translation : Tresi Murphy

1 Take over a territory, let geography be your guide, seek the unknown. These profoundly American motivations imbued the colonisation of a land that once was mapped out by the First Nations: however, today, these impulses seem to be out of date, overdone. It takes a certain naivety and a particular appetite for risk to attempt this type of travel experiment in the U.S. It also calls for an unprecedented aptitude to tell the story in a way that differs from a travelogue-a genre that had its codes smashed fifty years ago by Michel Butor's Mobile, ${ }^{1}$ his astonishing "study for a representation of the United States." To set off on a similar adventure in today's world, requires an attitude of ownership and a light touch, and this is where Daniel Canty and Patrick Beaulieu come in. What they refer to as their "transborder odyssey," which takes them from Canada to the United States, is guided by three separate indicators: the migration patterns of the Monarch butterfly, the direction of the wind, and luck. These projects, they say, are part of a naive science experiment, ${ }^{2}$ where the odyssey materialises along the produced and recorded tracks of an actual experience and journey-but also through the multiple, quirky and polymorphous versions of the account. This is the aspect that interests us most in this article. Contrary to current transmedia trends, where the constant renewal of narrative and creative forms caused by the "changes in our society and the use of new media" ${ }^{3}$ means that while fiction is easily dispersed over complementary delivery channels, ${ }^{4}$ literature remains frozen around the idea that fiction is stable and comes in one, everlasting form-once a novel is published, there are very few other versions in terms of format (hardback to paperback). Popular fiction does manage to spread out over other media, but for the most part, this happens in stages (a series based on one character, for example) and in the rollout of a specific universe. Popular series such as the Harry Potter books and the Millennium trilogy, are good examples of the current trend for making fiction available in a number of medianovels, comic books, films, television series, video games, fanfiction, mobile applications, etc.-according to a carefully orchestrated and coordinated plan. ${ }^{5}$ In 
general, this type of popular culture, transmedia literary incarnations are not associated with the more limited field of literature.

The multidisciplinary author and artist from Quebec, Daniel Canty, is somewhat of an exception in this area, as his literary projects reinvent themselves according to whatever channel he chooses, without submitting to the same "imperialist" coordination of other transmedia works, ${ }^{6}$ Canty manages to combine literary fiction and art exhibitions, cultural mediation projects and videos, websites and books. In recent years, Canty has paired up with the visual artist Patrick Beaulieu on three unique travel projects: Vector Monarca (2007), a journey that saw the pair follow Monarch butterflies from Quebec to Mexico; Ventury (2010), an expedition which involved travelling in the same direction as the wind from Chicago to the south east of the United States; and Vegas (2013), a trip where luck played the (arbitrary) role of navigator. The multiple perspectives of the experience, the sampling methods, but above all the but also the scattered appropriation of the various tracks seem to us, to exemplify the main feature of what we refer to as fluid fictions within these odysseysas, despite the fact that actual material artefacts are produced, it is the narratives, the invented and the fabulous, that come to the fore and appear in different formats and media. The Internet plays the decisive role of a bridge, like a space for transmission and transformation, and not merely a drop point. We choose $\mathrm{V}$ number two from the triple $\mathrm{V},{ }^{7}$ Ventury, in order to examine the way in which the journey was recorded, which will lead us to explore the issues of writing and representation through the trans-mediation of the traces of this journey.

\section{Context}

3 The Ventury project is the brainchild of visual artist Patrick Beaulieu. The original, ambitious objective was to follow the direction of the wind using Chicago, the "Windy City," as a starting point. In a blue, Ford Ranger truck nicknamed the "Blue Rider" with a weathervane and a windsock, Beaulieu, and a few companions, took off along the roads of America, wherever the wind took them. The expedition took place in Autumn 2010 and lasted 25 days. Three other artists took part: the architect and landscaper Alexis Pernet, the artist and writer Daniel Canty and the writer Dauphin Vincent. They each took it in turns as co-pilot beside Beaulieu, recording their own experiences, in their own way in a travel diary and on a roadmap. The immortalisation of their trip was for them a reflection, "the description or interpretation of the winds that blew, combined with the intensity of their emotions." ${ }^{8}$ The Ventury project was a risk-Beaulieu claimed, after the fact, that he would have been ready to abandon the Blue Rider offshore had the wind dictated. ${ }^{9}$ In addition to the logistical risk of an expedition that depended on factors that could not be controlled (the flight paths of butterflies, the wind, luck...), there was also the issue of the odyssey's costeffectiveness, and that of the artistic project that depended on it directly. The objective of the experiment went beyond a simple road trip around the U.S. and gathering anecdotes to tell later on. The integration of a resolutely artistic dimension to the adventure requires a triple experiment associated with a geo-poetic perspective, that "looks at the travelogue from three perspectives at once, scientific, philosophical and poetic." ${ }^{10}$ A writer that adopts this creative position is particularly sensitive to the geographical elements of the journey (landscapes, architecture, climate, etc.), which 
creates a more intense connection to the world. Geography remains but a human projection on space, and as Bertrand Westphal so rightly tells us, all geocriticism requires that we examine the interactions between human spaces and their literary representation-to uncover the cultural basis to this seizure of space by humans. ${ }^{11}$ Rather than objectively retracing the journey, instead it becomes a source of reflection and creativity that the artist can capture using a range of devices and tools such as a camera, a pencil, a paintbrush. For the writer experimenting with geopoetics, writing never corresponds to a faithful account of the journey (nor is it intended to), instead, it is always coloured with the author's own subjectivity, transposing their experience and keeping it alive through words. Geopoetics thus requires fluidity, fulfilling a need to account for the journey's unpredictable twists and turns rather than the end result, of a singular, rather than factual experience.

4 This vision is absolutely faithful to the spirit that has guided the creators of $V V V$, and the way they are explicitly open to the poetization of the experience and the world. In addition, letting go is crucial for the protagonists-a large part of Ventury comes from invention, unpredictability and dreaming: "Let the wind carry you. Give in to a higher force. Obey a reason that reason does not know." 12 The emphasis was obviously not on the destination, but on the journey, the chance events, the traces, the effect it had on the companions of the odyssey. In order to keep a record of their adventure, the artists undertook a sampling exercise: they selected a range of isolated elements that would bear witness to all they had seen, heard and experienced. They recorded numerous remnants of their adventure, traces of the name of a hotel, of a conversation with such and such, of the taste of a certain meal. A number of methods of capturing real events were used in order to record these samples, in the same way that this rich source of material was used and transmitted in different ways.

\section{Media used to capture the journey}

5 For all three transborder odysseys, the ways in which the experiences were recorded have a common thread. The basis being the inventive capacity of the artists to make connections and to create artistic meaning from the elements of the journey, this common thread initially took the form of limits. They gave themselves a mandate to travel through America in unique, original vehicles, specially designed for the project: the Monarca Mobile (a postal truck that was transformed into a veritable, travelling art gallery), the Blue Rider (a Ford Ranger truck with a weathervane and windsock) and the Magic Dart (a Dodge Dart with a wheel of fortune on the front bonnet). The artists inside these emblematic motors, followed particular paths, dictated by unpredictable parameters: the migration paths of Monarch butterflies, the direction of the wind and lady luck. So, along this wandering path, through changeable surroundings, they attempted to capture one-off, isolated elements, that they tried to randomly seize from the very continuity of the experience. This sampling process is complex, and magnified by the variability of the devices used.

6 Video, the favoured medium that combines sound, image and movement, was used on all three odysseys. Patrick Beaulieu filmed scenes that were evocative of the theme chosen for each expedition. For example, in the case of Ventury, he filmed the billowing movement of a curtain through an apartment window or quivering electric cables. These images were added to by still photography-taken with a Polaroid (in Vector 
Monarca) or a shared camera where the artists would take photographs of the elements of the landscape they encountered. The travellers also wished to keep a written account of their adventure. Each trip was an opportunity for Canty or his companions to keep a travel diary or a notebook in which they recorded their experiences. They wrote about the weather conditions, places they ate and slept, people they met, their geographical location. At times, these notebooks were also used for drawing diagrams or sketches of the places they went to. The "orientation table," a combination of a sketch and a map, made by Pernet and Canty, shows all of the city names and the places of reference ("Mississippi," "Cincinnati," "Louisville"), with, from time to time, notes: "Where we went. / What we saw. / Who we talked to. / What we ate. / The weather. / The books we found."; "When does a road start to look like a river? You need to start by losing the line of a lake."13

7 These notebooks made it possible to reflect randomly on the experience itself, allowing them to create a piece of fiction based on the reality they captured, a blurry distinction between real account and utter invention. In addition, in order to retain a trace of the journey's fluctuations, they traced their itinerary on a map, filling in the departure point and the arrival point of each day. Digital devices completed their arsenal: some traces were typed into a laptop of course, but Canty also used his smartphone to transmit their geographical position live, and in real time thanks to geolocation. In Vector Monarca, letters containing scraps of their odyssey (a piece of the map, a fragment of a poem, etc.) were sent every so often to the webmaster in Montreal who started the project's website using these elements.

8 Not only that but, the artists also chose to collect different objects connected to the project. For Vector Monarca, they gathered up the broken wings of Monarch butterflies, but also lots of paper documents linked to the theme (stickers, napkins...). For the Ventury, they brought back postcards that evoked the theme of wind, directly or indirectly. Every day, they had to visit a book shop or antique shop in whatever place they found themselves. This example also reveals another variable, that increased the unpredictability levels of their experience and how they grasped it: outside participation. The postcards are a good example. The sales assistants in the shops they visited acted as interpreters, in as much as they had to decipher Beaulieu and his acolytes' request and figure it out: "Do you have postcards of the wind?" The result depended on how the sales assistant understood this unusual request, literally or with amusement. The collective dimension also came into play with the relay system between companions (Ventury) and through the contributions from the webmaster (Vector Monarca).

9 This aspect comes to the fore in a different manner in the Vegas project. Throughout the duration of the trip, artists asked the individuals they bumped into on the way, to turn the wheel of fortune on the bonnet of the Dodge Dart (they included a police officer who was quite surprised by the car's additional feature...). According to the wheel, the artists then had to adopt a particular attitude (innocence, luck, contemplation...) and make connections with what they saw during that day. This meant that their expedition was a chance to turn the incidental into experience, as the artists were guided by chance meetings and the vagaries of nature (the wind or the migratory path of the butterflies).

Connected to Gregory Chatonsky's aesthetic of flux, the notion of incident refers to a "feeling that something is overflowing in the field of perception and never stops, it 
flows indefinitely as if nothing was ever autonomous again." ${ }^{14}$ This aesthetic tends to provoke incidents, to come up against uncontrollable events, dictated by outside forces, a state of mind in which Canty and his acolytes found themselves. The outside participation was thus crucial to the attempt to grasp the flux that constitutes the framework of their expeditions. The objects collected (butterfly wings, stickers...) were a means to extract a piece of the flux, in fragments, and the act of collecting these scraps was a way to preserve a trace. So, it was by using these scrappy elements, torn from their experience-"the cutting was an integral part of the digital flux"15-, stuck here and there on various documents and devices, that the artists attempted to give a shape and a body to a journey that was fundamentally unpredictable.

\section{The transmediation of experience}

11 To give shape, choose the angle, the frame, the lens. These are all things a photographer, sculptor, painter, writer does. We just mentioned the attitudes taken on by the travellers-we are a stone's throw from the three approaches to reality experimented by Italo Calvino in his collection of stories entitled Palomar, ${ }^{16}$ where the writing is in turn, descriptive, narrative and philosophical. We easily grasp the effect of the device, a theme that features prominently in this collection of articles, that works on two levels: the act of doing on the material; and the series effect, the temporality of the process. ${ }^{17}$ Shaping the real, approaching it with a given attitude or perspective (whether chosen, forced or imposed by chance), is one of the founding movements of Beaulieu and Canty's odysseys, but it is also a recurring movement, one that is reiterated, expressing the fiction generated by the journey in different ways.

The artistic approach associated with transborder odysseys is not about the simple transformation of the real into an aestheticized version, that follows on from the actual expedition period. It provides a framework instead-Beaulieu's art installations with Monarch butterfly wings, in fact, preceded Vector Monarca, and a particular interest in breath (el soplo) came before Ventury. The material, but just as symbolic transformation of the vehicles, is part of the poetic commitment to the adventure. It is important then, to see the work carried out to constitute a trace-whether it be the "geopoetic" map of their journey, the scribbled notebooks, the samples of butterfly wings and the video footage of the effects of the wind-as a metaphorical grasp of the real. The gesture is, of course, immediate as the odyssey takes place throughout the United States (the event is taking place here and now, it is imperative to keep traces of the experience as it happens), but it is also a gesture that is mediated through an aesthetic grasp, that removes the sample from the flux from which it is extracted, a gesture mediated by the intervention of time-the original temporal foothold fades away, leaving a multiplication of moments of the traces existence in its place. The work it takes to constitute these traces is never objective, never neutral, but the approach of Beaulieu, Canty and their companions pushes this formatting process, this manipulation, a notch further. Indeed, Beaulieu has created many artistic installations using the video footage and the objects collected on the road; alongside Canty, he holds screenings, exhibitions and multimedia performances, in different locations, whether during or after the odysseys, bringing an aestheticized version of an unchecked experiment of American space and culture, to life, by procuration or with a time shift. 
13 course, the three websites ${ }^{18}$ associated with the project, available in and out of step with the expeditions, contribute greatly to the longevity of these artistic events-the proof being that we still consult them today, as the role they play for us is informative. Nevertheless, their role is unequal, as the Vector Monarca site is the most detailed and elaborate addition to the odyssey of the three (while the structure and reach of Ventury and Vegas, mean they work as trailers for a film that we can't even imagine). In addition, beyond these variations, the shift in medium takes over, in as much as it changes the transmission and the experience-that of the reader, or, in this case of the viewer. While an informational or factual approach means we see websites as a means of stabilising material that would otherwise have been forgotten about, if we look closer at the media used we can see the progressive dilution of the sampling process. As second-level traces purposely put together using the traces collected by the travellers, the websites are more about remediation (as in Bolter and Grusin ${ }^{19}$ ), with a relationship of distance and homage, of rivalry and re-appropriation of the previous medium, to the original one.

On the website of the first expedition, ${ }^{20}$ the page by page reproduction of one of the Vector Monarca notebooks, denies the material nature of the object as it elevates it to trace status, but its digital avatar can be understood aesthetically-the way the pages are presented, the visual effects and browsing from one image to the next reduce the informational character of the archive, which is replaced by a distant perception of the experience-with five degrees of distance: subjective perception, drafted in words and images, the use of a material medium, the digitisation as pictures of the notebook and the insertion of the pictures into the architecture of a website. This clash between proximity and distance is at its height when browsing the websites, as the consultation adjusts itself according to specific expectations of digital culture (which refuses any temporal distance or shift from the get go), and a consultation that is also affected by the huge appetite for archive material that is constantly being fed by the same digital culture.

This type of remediation is all the more surprising when we see the aesthetic shift in the samples and materials associated with Beaulieu and Canty's odysseys. The VVV book is the sum of three Vs, a "geopoetic atlas," ${ }^{21}$ according to the authors, that brings together, by comparing and distinguishing, the adventures of Patrick Beaulieu and his acolytes. The book is both an initial contact with the experiences, and a meta take on the artistic approach, and it pushes the representation of the real even further. From the aestheticization of the archives, the explanation of the attitudes and the appearance of the tools (in the end, the maps were not useable), the intermedia relationship, from the book to the different media that contain the content represented in the book, might lead to confusion among some readers. This is not necessarily the case, and we make sense of the proposition when we understand it as a rewrite, as a shift. Through all of its occurrences, the odyssey goes beyond the iterative character of its forms of expression to enter into a recursive loop but with a constant shift factorfrom one time to the next, an extra distance is imposed, leaving room for greater subjectivity, aesthetic manipulation and fiction. It is only when we situate the overall VVV project, and all of its spinoffs, in its own specific media dynamic that we can grasp this logic, which is fluid because it is based on fluctuation, at its deepest level.

Hybrid, 5 | 2018 

variation. Well-informed readers know that his unusual novel Wigrum, ${ }^{22}$ and encyclopaedic work of crumbling fiction came into being from fictional material that was originally used to fill up a website of a multimedia company. Canty's fictions are fluid in nature, they migrate and transfuse, crystallising into distinct, connected but clearly autonomous manifestations. Ventury is a great example of this fluidity. Canty kept a travel diary on his wind-following trip through Eastern America. The VVV book, that covers all three trips, includes a version of the notebook over nine pages.

However, almost simultaneously, Canty published Les États-Unis du vent with a literary publisher that is referred to generically as a "récit" (a usual indicator of an autobiographical account that leaves room for a certain amount of fictionalisation). This 283-page long narrative reports Canty's own experience as part of the Ventury odyssey, in which he uses the same timeline over ten days as the principle of the account of the experience. The nine pages of the notebook that appear in VVV are in line with the book itself (large format, columns, pictures, graphics) and with its status as a geopoetic atlas, as well as a trace of the traces (undertaking, as the work does overall, an examination of the artistic approach); in comparison, Les États-Unis du vent has no graphics, and is more of a memoir, half-travel essay, half- work of fiction, that places the experience at a distance. The transformation occurs slowly, from Canty's original (inaccessible) notebooks, to the extract on the Ventury website and the nine, mainly descriptive pages in VVV, to the narrative and reflective expanse of Les ÉtatsUnis $d u$ vent. The referential basis remains the same, obviously, as is evident from certain passages that remain from one version to another or that are fiddled with in the writing process.

The reach of the piece relies heavily on the media used (as it defines the circulation, readership and codes) and on the very mutation of fiction-Les États-Unis du vent as it develops, in as much as it is a rewrite of past states, a critical discourse on American culture and society. The intertexts are surprisingly varied, from the writings of oliver Sacks and Oscar Wilde, at the start, to "Un Canadien errant," a song written at the end of the 19th century by Antoine Gérin-Lajoie, Michael Cimino's film "The Deer Hunter," and pseudo-references to television like "The Donut Monster of Northern Pennsylvania." The long version of Canty's notebooks is made from a vast and mixed fabric of (often fleeting) mentions of varied cultural content-from the writer of course, but also from the spaces that the travellers make their own, as time goes on. This cultural "quilt," in line with American traditional and popular practices, makes the wandering journey of Beaulieu, Canty and their consorts, part of a social and identitybased exploration.

Strangely, the road itself is given very little space in this study. However, as Victoria Stanton reminds us: "The road of multiple possibilities [...] becomes [for Beaulieu] an in-between place where performative demonstrations of intuition, necessity and serendipity take place. Attentive considerations to an evanescent present thrive within this performative attitude. ${ }^{23}$ By taking to the road, a non-place that is nevertheless extremely busy, an eminently concrete incarnation of the digital flux we speak of in this article, the transmedia odysseys of Beaulieu and Canty manage to load this recursive movement with meaning. The occurrences of these narratives that testify to the traces of the sampling of the American flux all converge toward an idea of an impressionistic but nevertheless convincing grasp, of a society on the way down-in

Hybrid, 5 | 2018 
fact, Canty describes these adventures, in the end, as a sort of a "chronicle of disappearances." ${ }^{24}$ We could easily see Les États-Unis du vent as a sort of extrapolation of the travel diary he kept during his time aboard the Blue Rider (because the issue of remaining faithful to the experience as it happened is no longer on the table). This relationship to fiction is a consequence of the relationship Canty has with the real, seeing that the very path of the odysseys led to the creation of a parallel reality. ${ }^{25} \mathrm{As}$ the artist has harnessed a range of media using multiple voices and appealing to multiple audiences, in the end, a long-term view is the only thing that will allow distance, a shift, a rewrite and a new, singular re-appropriation of material that belongs as much to the protagonists' reality as it does to their imagination.

\section{Conclusion}

From many angles (media, process, generic), the transmedia and transborder project VVV in which Daniel Canty takes part, takes a step away from the general idea of a literary work, as a defined, stable entity that comes in only one format. Canty works from a more fluid angle on his fiction, that he creates according to his own genres, formats and circumstances to produce variants that are expressive in different ways. Taking Ventury, the second V in this vast project, as a case study, we showed the propensity of the artists for a sampling of the real, which is then used as the basis for a writing-rewriting process on the traces of the adventure. In itself, the artistic approach chosen in this case is associated with a fluctuating, subjective perspective of travelling, geopoetics-that invests its constant back and forth between geographical references and spatially grounded manifestations of cultural identity. The flux aesthetic is then expressed as much through the different gathering processes used on the journey (video, photos, travel diary, objects collected, etc.) as it is through the different media (both autonomous and interconnected) used to crystallise the experience of the journey (books, websites, videos and cultural mediation projects) once it has taken place. The entire set-up is complex in terms of the manifestations and the shifts that occur in the semantic reach of these manifestations, and seems to be both a mechanism for grasping cultural flow and American naturalism as its mimetic, recursive and tangential reproduction, in the form of fluid fictions.

21 In such projects, there is a fundamental tension that illustrates the extent to which technical imaginary worlds are intertwined with one another in digital culture. On the one hand, they feature the armada of mechanisms of predictability and inclusion of images the technology allows-heavy machinery that obeys an implacable physical logic. Rules, constraints, genres allow the mediation of a previously formless reality. This is what the triple $\mathrm{V}$ travellers used to give meaning to their journey, a manner to grasp the America they covered, mapped and described. The notion of flow was also present, the original meaning that we associated with liquid, water and rivers is given a new slant that has yet to be categorised, but that evokes the uncontrolled overabundance of data. Wind and luck alike, manage to escape our grasp, but, as Canty concludes in États-Unis du vent, "however, the wind, as the expression goes, the wind was with us. Perhaps, the fact that we had trusted it meant we could now control it?"26 The constant question of our, hoped or suspected, ability to control the real through our art, forms the basis of much of contemporary aesthetics. 


\section{BIBLIOGRAPHY}

BEAULIEU Patrick, Vector Monarca, 2007. [Online] http://vectormonarca.com/fr/index.php [accessed 14 February 2018].

BEAULIEU Patrick, Ventury, 2010. [Online] http://venturyodyssey.patrickbeaulieu.ca/index.html [accessed 14 February 2018].

BEAULIEU Patrick, Vegas, 2012. [Online] http://vegasodyssey.patrickbeaulieu.ca/index.html [accessed 14 February 2018].

BEAULIEU Patrick and CANTY Daniel, VVV. Trois odyssées transfrontalières, Montréal, Éditions du passage, 2015.

BOLTER Jay David and GRUSIN Richard, Remediation. Understanding new media, Cambridge, MIT Press, 1999.

BOUVET Rachel and MARCIL-BERGERON Myriam, "Pour une approche géopoétique du récit de voyage," Arborescences, no. 3, July 2013. [Online] https://www.erudit.org/fr/revues/arbo/ 2013-n3-arbo0733/1017364ar/ [accessed 15 January 2018].

BuTOR Michel, Mobile. Étude pour une représentation des États-Unis, Paris, Gallimard, 1962.

CALVINo Italo, Palomar, Paris, Seuil, 1985.

CANTY Daniel, Wigrum, Chicoutimi, La Peuplade, 2011.

CANTY Daniel, "Patrick Beaulieu. Petite fabrique de l'âme," esse arts + opinion, no. 75, Springsummer 2012, p. 43. [Online] https://www.erudit.org/fr/revues/esse/2012-n75-esse088/66429ac/ [accessed 14 February 2018].

CANTY Daniel, Les États-Unis du vent, Chicoutimi, La Peuplade, 2014.

CANTY Daniel and KlEIN Anne, "Entretien - Questions de temps. Création, archives et numérique," in Audet René (dir.), CÉFAN seminar "Médiations numériques de la culture," Université Laval, December $1^{\text {st }}, 2016$, [Online] http://www.crilcq.org/fileadmin/CRILCQ/Video/

CEFAN_2016-12-01_Klein-Canty.mp4 [accessed 14 February 2018].

CHATONSKy Grégory, “Esthétique du flux,” Rue Descartes, vol. 1, no. 55, 2007, p. 86-99.

GROUPIERRE Karleen, "Enjeux des transmédias de fiction en termes de création et de réception," doctoral thesis in arts, philosophy, aesthetic, Université Paris 8, 2013.

GrouPIERRE Karleen, “Le transmédia: un dépassement du médium ?," Appareil, vol. 18, 2017. [Online] http://appareil.revues.org/2403 [accessed 15 January 2018].

JENKINS Henry, “Transmedia Storytelling 101," Confessions of an Aca-fan, 21 March 2007. [Online] http://henryjenkins.org/blog/2007/03/transmedia_storytelling_101.html [accessed 13 April 2018].

ORTEL Philippe (dir.), Discours, image, dispositif, Paris, L'Harmattan, 2008.

RYAN Marie-Laure, "Narration in Various Media," dans Hühn Peter et al. (dir.), The Living Handbook of Narratology, Hambourg, Hamburg University, October 2014. [Online] http://www.lhn.unihamburg.de/article/narration-various-media [accessed 13 April 2018]. 
STANTON Victoria, “Trajectoires performatives. VVV : une trilogie d'odyssées transfrontières,"

Inter, no. 118, autumn 2014, p. 67-69.

WestPHAL Bertrand, "Pour une approche géocritique des textes," Vox poetica, 2005. [Online]

http://www.vox-poetica.org/sflgc/biblio/gcr.html [accessed 16 April 2018].

\section{NOTES}

1. Michel Butor, Mobile. Étude pour une représentation des Etats-Unis, Paris, Gallimard, 1962.

2. Daniel Canty, "Patrick Beaulieu. Petite fabrique de l'âme," esse arts + opinion, no. 75, Springsummer 2012, p. 43. [Online] https://www.erudit.org/fr/revues/esse/2012-n75-esse088/66429ac/ [accessed 14 February 2018].

3. Karleen Groupierre, "Le transmédia: un dépassement du médium ?," Appareil, vol. 18, 2017, p. 75. [Online] http://appareil.revues.org/2403 [accessed 15 January 2018].

4. Attributed to Henry Jenkins due to his seminal work on the culture of convergence and the definition of transmedia or transmedia storytelling that crystallizes in Marie-Laure Ryan's expression: "The spreading of narrative content across multiple media platforms." ("Narration in Various Media," in Peter Hühn (dir.), The Living Handbook of Narratology, Hamburg, Hamburg University, 2014. [Online] http://www.lhn.uni-hamburg.de/article/narration-variousmedia [accessed 15 January 2018]). More specifically, Jenkins, as early as 2007, explained it thus: "Transmedia storytelling represents a process where integral elements of a fiction get dispersed systematically across multiple delivery channels for the purpose of creating a unified and coordinated entertainment experience. Ideally, each medium makes its own unique contribution to the unfolding of the story" ("Transmedia Storytelling 101," Confessions of an Aca-fan, March 21, $2007 . \quad$ [Online] http://henryjenkins.org/blog/2007/03/ transmedia_storytelling_101.html [accessed 15 January 2018]).

5. Corresponding to what Karleen Groupierre refers to as "cross-media": "A range of media that are all part of the same creative, coherent universe that are dispersed in a coordinated, synchronized way and delivered to the public as a whole" (Karleen Groupierre, "Enjeux des transmédias de fiction en termes de création et de réception," thesis in arts, philosophy, aesthetic, Université Paris 8, 2013, p. 31).

6. Without necessarily being limited to digital media.

7. A book that brought all three projects together in one work was published: Patrick Beaulieu and Daniel Canty, VVV. Trois odyssées transfrontalières, Montréal, Éditions du passage, 2015.

8. Patrick Beaulieu and Daniel Canty, VVV. Trois odyssées transfrontalières, Montréal, Éditions du passage, 2015, p. 103.

9. As Canty and Beaulieu's presentation entitled "Jours de chance : trois odyssées transfrontières à travers l'Amérique," for the "La recherche-création: territoire d'innovation méthodologique" conference at the University of Quebec, Montréal in 2014. [Online] http:// www.methodologiesrecherchecreation.uqam.ca/?page_id=575 [accessed 14 February 2018].

10. Rachel Bouvet and Myriam Marcil-Bergeron, "Pour une approche géopoétique du récit de voyage," Arborescences, n 3, July 2013, p. 1. [Online] https://www.erudit.org/fr/revues/arbo/ 2013-n3-arbo0733/1017364ar/ [accessed 15 January 2018].

11. "Is it not time to think of placing literature in relation to space, to promote a poetic géocritique, not to examine the way space is represented in literature, but more the interaction between human spaces and literature, one of the major issues in the determination/ indetermination of cultural identities?" (Bertrand Westphal, "Pour une approche géocritique des textes," Vox poetica, 2005. [Online] http://www.vox-poetica.org/sflgc/biblio/gcr.html [accessed 15 January 2018]. 
12. Daniel Canty, Les États-Unis du vent, Chicoutimi, La Peuplade, 2014, p. 11.

13. Patrick Beaulieu et Daniel Canty, VVV. Trois odyssées transfrontalières, Montréal, Éditions du passage, 2015, p. 114-115.

14. Grégory Chatonsky, "Esthétique du flux," Rue Descartes, vol. 1, no. 55, 2007, p. 86.

15. Grégory Chatonsky, "Esthétique du flux," Rue Descartes, vol. 1, no. 55, 2007, p. 95.

16. Italo Calvino, Palomar, Paris, Seuil, 1985.

17. For Philippe Ortel, the device is "a matrix of potential interaction, an interactional matrix," referring to its technical, pragmatic and symbolic complexity (Philippe Ortel [dir.], Discours, image, dispositif, Paris, L'Harmattan, 2008, p. 6).

18. Patrick Beaulieu, Vector Monarca, 2007. [Online] http://vectormonarca.com/fr/index.php; Vegas, 2012. [Online] http://vegasodyssey.patrickbeaulieu.ca/index.html; Ventury, 2010. [Online] http://venturyodyssey.patrickbeaulieu.ca/index.html [accessed 14 February 2018].

19. Jay David Bolter and Richard Grusin, Remediation. Understanding new media, Cambridge, MIT Press, 1999.

20. A copy can also be seen in VVV, on pages $62 \mathrm{sq}$., with the legend Carnet de science naïve. [Online] http://www.vectormonarca.com/fr/carnet.php [accessed 14 February 2018].

21. See the blurb for the book on the Éditions du passage website. [Online] http:// www.editionsdupassage.com/fr/livre/beau-livre/89/vvv [accessed 14 February 2018].

22. Daniel Canty, Wigrum, Chicoutimi, La Peuplade, 2011.

23. Victoria Stanton, "Trajectoires performatives. VVV : une trilogie d'odyssées transfrontières," Inter, no. 118, Autumn 2014, p. 68.

24. Patrick Beaulieu and Daniel Canty, VVV. Trois odyssées transfrontalières, Montréal, Éditions du passage, 2015, p. 212.

25. Read Canty's remarks on fiction and reality to Anne Klein (Daniel Canty and Anne Klein, "Entretien - Questions de temps. Création, archives et numérique," in René Audet [dir.], CÉFAN seminar "Médiations numériques de la culture," Université Laval, 1 December 2016. [Online] http://www.crilcq.org/fileadmin/CRILCQ/Video/CEFAN_2016-12-01_Klein-Canty.mp4 [accessed 14 February 2018].)

26. Daniel Canty, Les États-Unis du vent, Chicoutimi, La Peuplade, 2014, p. 257-258.

\section{ABSTRACTS}

This article examines the transmedia processes of literary fiction, especially the case of three artistic and literary explorations conducted by Patrick Beaulieu and Daniel Canty, all gathered in the book VVV. Sampling reality during their journeys on American roads, Beaulieu and Canty mediate their experiences through various artifacts (exhibitions, websites, literary works). Canty's fictions displays a truly fluid character, each of their occurrences showing a displacement in space, as much as through its forms and meanings. The comparative examination of these variations illustrates the increasing distance between traces collected and the very experience from which they derive.

\section{INDEX}

Keywords: apparatus, contemporary literature, cyberculture, flux, rewriting, transmedia 


\section{AUTHORS}

\section{RENÉ AUDET}

René Audet is a Professor in the Literature, Theatre and Film Department of l'Université Laval and a member of the Centre de recherche interuniversitaire sur la littérature et la culture québécoises (CRILCQ). His work, sponsored by the Social Sciences and Humanities Research Council of Canada, is focused on novels and short stories, contemporary narratives, literature and digital culture, as well as digital publishing. He is the editor in chief of the online scientific review temps zéro and the series editor of "Contemporanéités" published by Éditions Nota bene, where he has also co-directed multiple reviews and collective works on contemporary literature. He runs the Lab Ex situ Études littéraires et technologie (http://ex-situ.info).

\section{CHARLES-ANTOINE FUGÈRE}

Charles-Antoine Fugère is a Master's student in literaty studies at Université Laval. His research focuses on contemporary literature and its digital expression. In the Fall 2017 he started his thesis "The constrained reader: reading predetermination in a digital context in Déprise, The Stanley Parable et Chronique(s) d'Abîme," supported by the Social Sciences and Humanities Research Council of Canada. A Study Member of CRILCQ (site Université Laval), he is an Auxiliary Researcher for a project on digital books. He is also working as an Auxiliary Researcher for the online course "Approches de la culture numérique” taught at l'Université Laval. 